\title{
INFLUENCE OF FEEDING INTENSITY ON CORPOREAL DEVELOPMENT, BODY COMPOSITION AND SEXUAL MATURITY IN FEMALE RABBITS
}

\author{
Kinga Fodor, S. Gy. FeKeTE* , L. ZÖldÁG, A. BERsÉnyI, A. GÁSPÁRdy, \\ Emese ANDRÁSOFSZKY, Margit KuLCSÁR and F. ESZES \\ Institute of Animal Breeding, Nutrition and Laboratory Animal Science, \\ Faculty of Veterinary Science Budapest, Szent István University, \\ H-1400 Budapest, P.O. Box 2, Hungary
}

(Received November 8, 2000; accepted September 5, 2001)

Twenty-six 6-week old female New Zealand White rabbits were divided into two groups: ad libitum (AL) and 70\% restricted (RS) feeding. At the beginning of the experiment the liveweights were practically the same: $0.99 \pm 0.08$ vs. $1.01 \pm$ $0.08 \mathrm{~kg}$ in group AL and RS, respectively. At 18 weeks of age the body weight of Group RS rabbits was $84.7 \%(3.14 \pm 0.24 \mathrm{~kg})$ of the group AL $(3.71 \pm 0.31 \mathrm{~kg})$. The apparent digestibility of crude protein was significantly $(\mathrm{p}<0.001)$ higher in Group RS than in Group AL $(76.5 \pm 1.4$ vs. $73.0 \pm 2.7 \%)$. The daily water consumption was significantly $(\mathrm{p}<0.05)$ higher $(3.5 \mathrm{ml} / \mathrm{g}$ DM intake) in Group RS as compared to Group AL (1.9 ml/g DM). Since the average body weight in Group RS at 18 weeks was the same as that of Group AL at 14 weeks of age $(3.14 \mathrm{~kg})$, the comparison of the live body measures and indices was based on these ages. Animals fed ad libitum or restricted show no differences at the defined age in most live body measurements except in heart girth and rump width, which were significantly $(\mathrm{p}<$ $0.05)$ shorter in Group AL than in Group RS $(29.3 \pm 0.8,5.7 \pm 0.5$ and $30.7 \pm 1.0$, $6.2 \pm 0.3 \mathrm{~cm}$, respectively). Body capacity was significantly $(\mathrm{p}<0.05)$ smaller in Group AL, as the head capacity-body capacity proportion was significantly ( $\mathrm{p}<$ $0.05)$ higher in Group AL than in Group RS $(1653.1 \pm 134.5,22.0 \pm 2.5$ and $1913.7 \pm 168.7,17.7 \pm 1.9$, respectively). Due to restricted feeding the growth of the head proved to be less intensive than that of the body at the same body weight. The body in these does tended to be wider. Since the head in comparison to length or capacity of the body was smaller in does fed $70 \%$ of ad libitum, it could be concluded that the development of body parts of restricted-fed does was unequal (allometric growth). The effect of feed restriction reflected in lower dry matter and fat, and a higher ash and protein content both in total body and in dry matter composition of rabbits at 18 weeks of age. Restricted feeding delayed sexual maturity (69 vs. $92 \%$ of rabbits) with later starting ovarian activity, weaker ovarian responsiveness, and a smaller number of tertiary follicles on the ovarian surface.

Key words: Restricted feeding, growing female rabbit, body measures, chemical composition, sexual maturity

\footnotetext{
*Corresponding author; E-mail: safekete@univet.hu; Fax: +36 (1) 478-4128
} 
Longevity and lower replacement rate of rabbit does are desired features both in production and in laboratory animal breeding (Coudert and Lebas, 1985). For young does, the feeding system, therefore, strongly depends on the expected age at the first mating. Ad libitum feeding, together with early mating (at $75-80 \%$ of adult body weight, at 14-15 weeks of age), leads to favourable results in obtaining the first litter. However, in the practice it is recommended to restrict the feeding of young does in order to postpone the first mating until the age of 17-18 weeks to prevent their extreme fattening. The recommended level of restricted feeding is usually $35 \mathrm{~g} /$ day $/ \mathrm{kg}$ liveweight, when a reproduction diet of more than $10.48 \mathrm{MJ} / \mathrm{kg}$ is used (Maertens, 1995). According to Eiben et al. (1998), feeding intensity influences the first mating age in rabbit does: in case of ad libitum feeding and one day fasting per week, $66 \%$ and $54 \%$ of does, respectively, reach mating size ( 3.4 to $3.5 \mathrm{~kg}$ ) at the age of 17 weeks. At the same time, does fed with feed withdrawal of $9 \mathrm{~h}$ per day (equivalent to $130 \mathrm{~g} /$ day feed intake) can be mated only at the age of 19-20 weeks. Szendrö et al. (1988) recommended applying the eating time reduced to 9-12 h daily between 4 and 12 weeks of age. Tag-El-Den et al. (1988) also proposed diminished nutrient supply in fat female rabbits.

A 4-day flushing after a restriction period can be effective in inducing oestrus. However, Maertens (1997) found only a non-expressed advantage of flushing on reproductive performance of female rabbits. High-energy density feeds $(11.22 \mathrm{MJ} / \mathrm{kg} \mathrm{DE})$ failed to compensate for the energy deficiency of does remated on day 10 following their kindling (Parigi Bini et al., 1996) and the conception rate remained low. Restricted feeding during puberty may delay sexual maturity by suppressing hypothalamic GnRH release and pituitary LH/FSH secretion. In underfed heifers sexual maturity occurred later and at smaller body weight, leading to a delay in resumption of cyclic ovarian activity after calving and lengthened conception intervals (Huszenicza et al., 1988). Excessive fat deposition, on the other hand, may also delay sexual maturity (Fekete, 1995).

It is well known in other species (heifer, gilt) that sexual maturity, i.e. the onset of the first fertile oestrus and ovulation (puberty) depends mostly on body weight and body composition, rather than on the age. Rommers et al. (1999) stated that the rearing period is the best occasion to influence body development for optimum reproductive performance. The findings of Ayyat et al. (1995) showed that the live body weight to thigh length index could be used for classification of rabbits for production to different grades both for marketing and breeding. It is commonly accepted that feed efficiency is inversely proportional to the dietary energy level. Rabbits try to adjust their voluntary feed intake to their actual daily dietary DE demand. Therefore, the change of dietary energy content cannot be applied in rabbits for feeding at a different energy level. Hence the quantitatively restricted feeding ( $70 \%$ of ad libitum) was used in this work to test the effect of feeding intensity on the development of different body parts, chemical composition and sexual maturity in growing, female New Zealand White (NZW) rabbits. 


\section{Materials and methods}

Animals

Twenty-six 5-week-old female NZW rabbits were used in the study. The experimental animals originated from the outbred stock of LAB-NYÚL BT. (Gödöllö).

\section{Housing}

The experiment was carried out in the animal facilities of the Institute of Animal Breeding, Nutrition and Laboratory Animal Science, Faculty of Veterinary Science Budapest, Szent István University. The animals were kept in wire mesh cages individually. The ambient temperature was $20 \pm 2{ }^{\circ} \mathrm{C}$ and the relative humidity approx. 65\%. To avoid the effect of photoperiod (Adam and Robinson, 1994), controlled daily lighting periods were applied (16:8 h light to dark). The rabbits were allowed to drink tap water ad libitum.

\section{Nutrition}

All of the rabbits were fed a commercial diet (Table 1) containing 15.2\% crude protein, $14.1 \%$ crude fibre and $11.5 \mathrm{MJ} / \mathrm{kg}$ DE (Bácska Ltd). The feeding trial lasted between the age of 6 and 18 weeks.

\section{Experimental design}

According to the feeding intensity, two groups were constituted. In Group AL, rabbits $(\mathrm{n}=13)$ were fed ad libitum and their feed intake was recorded daily. Their sibs $(\mathrm{n}=13)$ in Group RS were fed restricted, namely $70 \%$ of ad libitum (pair feeding). Based on the individual body weight at 6 weeks of age the sisters were randomly distributed into groups to obtain identical average body weights and minimum variance.

\section{Digestibility study}

At the 11th week of age of rabbits the apparent digestibility of major nutrients of the diet fed was determined (Fekete and Gippert, 1981) using the chemical methods of the Codex Pabularis Hungaricus (1990). During this test, the water consumption was also measured.

\section{Live body measurements}

The body indices were calculated from the body measurements taken down during the experiments. Most of the body indices used in this investigation are widely applied in other domestic species (Jakubec et al., 1985; Gáspárdy et al., 2001; Püski et al., 2001) in the same or in a modified form. Some of the indi- 
ces (index of head capacity, index of ear surface) have been created by us in order to evaluate the body development of the rabbit.

\section{Table 1}

Natural composition and analysed nutritive value of the diet

\begin{tabular}{lr}
\hline \multicolumn{1}{c}{ Ingredients } & $\%$ \\
\hline Barley & 38.0 \\
Wheat & 10.0 \\
Maize & 15.3 \\
Wheat bran & 6.0 \\
Extracted sunflower meal & 16.5 \\
Alfalfa meal & 11.7 \\
Lysine & 0.2 \\
Limestone & 1.5 \\
Salt (NaCl) & 0.3 \\
Vitamin-mineral premix & 0.5 \\
\hline Total & 100.0 \\
\hline \multicolumn{1}{c}{ Major nutrients } & \\
\hline & $\%$ \\
\hline Dry matter & 91.9 \\
Ash & 7.0 \\
Crude protein & 15.2 \\
Crude fibre & 14.1 \\
Ether extract & 1.8 \\
N-free extract & 53.8 \\
\hline DE, MJ/kg & 11.5 \\
\hline
\end{tabular}

The following measures of the live animals were recorded weekly: body weight (BW); trunk length (TL), from base of tail to tuber scapulae; head length (HL), from nose to nape (1st cervical vertebra); head height $(\mathrm{HH})$, between the top of head and the lower jaw; head width (HW), between the left and right margo infraorbitalis; ear length (EL), in case of both ears from base to top of ear; ear width (EW), in case of both ears between the margins at the widest points; heart girth (HG), thoracic circumference behind the shoulder-blade; rump width (RW), between the left and right tuber coxae; fore cannon (antebrachium) length (FCL), in case of both arms from elbow to wrist; rear cannon (crus) length (RCL), in case of both legs from knee to ankle.

From the given data, the following indices were calculated:

Index 1: head capacity $=[(\mathrm{HW} \times \mathrm{HH}) / 2 \times \pi] \times \mathrm{HL}$

Index 2 : ear surface $=(\mathrm{EL} \times \mathrm{EW}) / 2$ 
Index 3: fore cannon-rear cannon proportion $=\mathrm{FCL} / \mathrm{RCL} \times 100$;

Index 4: fore cannon-body weight proportion $=\mathrm{FCL} / \mathrm{BW} \times 10$;

Index 5: body capacity $=(\mathrm{TL} \times \pi) / 3 \times\left(\mathrm{R}^{2}+\mathrm{R} \times \mathrm{r}+\mathrm{r}^{2}\right)$

$$
\begin{aligned}
& \mathrm{R}=1 / 2 \times \mathrm{HG} / \pi, \\
& \mathrm{r}=1 / 2 \times \mathrm{RW} ;
\end{aligned}
$$

Index 6: head capacity-body capacity proportion $=($ index $1 /$ index 5$) \times 100$;

Index 7: body weight-heart girth proportion $=(\mathrm{BW} / \mathrm{HG}) \times 1000$;

Index 8: trunk length-rump width proportion $=(\mathrm{TL} / \mathrm{RW}) \times 10$;

Index 9: extremities-trunk proportion $=(\mathrm{FCL}+\mathrm{RCL}) / \mathrm{TL}$.

\section{Body composition}

To determine the chemical components in the body, 10 and 26 rabbits were euthanised by i.p. pentobarbital (Nembutal inj. A.U.V., Phylaxia-Sanofi, Budapest) overdose at 6 and 18 weeks of age, respectively. For details of methodology see Fekete and Brown (1993).

\section{Checking of the sexual maturity}

In order to follow ovarian (LH receptors) and pituitary (LH responsiveness) activities the following hormonal treatments were used: Group AL: hCG treatment (Choriogonin inj. 1500 IU, Gedeon Richter Chemical Works, Budapest), $50 \mathrm{IU} /$ doe, i.m.; $\mathrm{n}=7$ ) and GnRH treatment (Receptal inj. A.U.V., Hoechst Vet. GmbH, Munich), $0.8 \mu \mathrm{g} / \mathrm{doe}$, s.c., $\mathrm{n}=6$ ), and Group RS: GnRH treatment (sibs to the hCG treated animals in Group AL) and hCG treatment $(n=6)$. Age at the hormone treatments was 8,10,12 and 17 weeks. For details of the principles of the doses chosen see Zöldág (1990). Colour and swelling of the external genitalia were observed on Days 2 and 5 following hormone treatments. Animals in oestrus were identified by teaser males. Blood plasma progesterone levels (P4) were determined from samples collected after anaesthesia (Vetranquil 1\% inj., Phylaxia-Sanofi, Bp., 0.1-0.2 ml/doe) from the ear vein according to Nagy et al. (1998). Blood samples were collected 8 days after hormone treatment. Ovaries and uteri of euthanised does were removed. The number of follicles in different stages of development on the ovarian surface was counted. Histological sections were made from the ovaries and uteri.

\section{Ethical issues, statistical analysis}

The experiment was approved by the Animal Use and Care Administrative Advisory Committee of the Municipal Veterinary Service for Animal Protection. Student's $t$-test and one-way analysis of variance according to the procedure of SPSS (Nouris, 1988) were used for the statistical evaluation of data. 


\section{Results and discussion}

Average body weight at 18 weeks of age was significantly $(\mathrm{p}<0.001)$ higher in Group AL as compared to Group RS $(3.71 \pm 0.31 \mathrm{~kg}$ vs. $3.14 \pm 0.24 \mathrm{~kg})$. In Group RS the average daily gain proved to be lower $(25.5 \pm 5.6$ vs. $32.4 \pm$ $3.2 \mathrm{~g}$ ). Since the increase in body weight of Group RS was relatively higher (78\% of Group AL) than the level of feed restriction (70\%), this might be due to the better digestibility of crude protein $(\mathrm{CP})$, the increased water consumption and probably the higher intake of caecotroph (Fekete and Bokori, 1985).

The apparent digestibility of major nutrients did not differ significantly in Group AL and RS (Table 2), except for crude protein ( $<0.001,73.0 \pm 2.7$ vs. $76.5 \pm 1.4 \%$ ). This tendency is similar to the results of Fekete and Gippert (1981), who found an improvement in the digestibility of all nutrients but fat after feed restriction. Due to its improved digestibility, the CP content of both total body and dry matter increased (Table 4). The animals of Group AL had poorer feed conversion efficiency (5.29 vs. 4.73; P>0.05).

Table 2

Digestibility of nutrients, $\%$ (mean $\pm \mathrm{SD} ; \mathrm{n}=13$ )

\begin{tabular}{llll}
\hline \multicolumn{1}{c}{ Nutrients } & Group AL & Group RS & P \\
\hline Dry matter & $58.51 \pm 2.26$ & $59.17 \pm 1.41$ & $>0.05$ \\
Ether extract & $79.25 \pm 1.51$ & $80.04 \pm 1.59$ & $>0.05$ \\
Crude protein & $73.01 \pm 2.72$ & $76.53 \pm 1.37$ & $<0.001$ \\
Crude fibre & $14.72 \pm 3.92$ & $14.72 \pm 3.72$ & $>0.05$ \\
NFE & $70.87 \pm 1.91$ & $71.48 \pm 0.97$ & $>0.05$
\end{tabular}

Group AL: ad libitum; Group RS: 70\% restricted, NFE: N-free extract

The rabbit generally drinks twice as much water as its dry matter intake (Cizek, 1961). The daily water consumption in Group RS was higher $(335.71 \pm$ $93.70 \mathrm{ml}$, i.e. $3.5 \mathrm{ml} / \mathrm{g} \mathrm{DM}$ intake) than in $\mathrm{AL}$ animals $(267.81 \pm 51.16 \mathrm{ml}$, i.e. $1.9 \mathrm{ml} / \mathrm{g} \mathrm{DM})$. The significantly $(\mathrm{p}<0.05)$ increased water consumption may have achieved satiety in rabbits. The extra water intake was only partly retained in the body, causing a lower dry matter content of the whole body (Table 5).

The average body weight in Group RS at 18 weeks of age was as much as that in Group AL at 14 weeks $(3.14 \mathrm{~kg})$. Therefore, the comparison of live body measurements and indices was based on these ages (Tables 3 and 4). Animals fed ad libitum or restricted did not show any differences at the defined age in most live body measures except in heart girth and rump width, which were significantly smaller in Group AL than in Group RS $(29.3 \pm 0.8,5.7 \pm 0.5$ and 30.7 $\pm 1.0,6.2 \pm$ $0.3 \mathrm{~cm}$, respectively). Most of the calculated indices were also the same. However, index 5 was significantly lower in Group AL and index 6 was significantly higher 
in Group AL than in Group RS $(1653.1 \pm 134.5,22.0 \pm 2.5$ and $1913.7 \pm 168.7$, $17.7 \pm 1.9$, respectively). Due to restricted feeding the growth of the head proved to be less intensive than that of the body at the same body weight. The body of these does tended to be wider, possibly in order to reach the sexual and breeding maturity. Since the head in comparison to length or capacity of the body was smaller in does fed $70 \%$ of ad libitum, it can be concluded that the development of does fed restricted tended to be unequal (allometric growth, Huxley, 1932).

Table 3

Body size characteristics in female New Zealand White rabbits (mean \pm SD)

\begin{tabular}{|c|c|c|c|c|c|c|c|c|}
\hline \multirow{3}{*}{ Live body measures } & \multirow{2}{*}{\multicolumn{2}{|c|}{$\begin{array}{l}\text { Before the trial } \\
(\mathrm{n}=26)\end{array}$}} & \multirow{2}{*}{\multicolumn{2}{|c|}{$\begin{array}{c}\begin{array}{c}\text { Group AL } \\
(\mathrm{n}=13)\end{array} \\
\text { Week } 14\end{array}$}} & \multirow{2}{*}{\multicolumn{2}{|c|}{$\begin{array}{c}\text { Group RS } \\
(\mathrm{n}=13)\end{array}$}} & \multirow{2}{*}{\multicolumn{2}{|c|}{$\begin{array}{c}t \text {-test } \\
\text { (between AL-RS) }\end{array}$}} \\
\hline & & & & & & & & \\
\hline & mean & $\pm \mathrm{SD}$ & mean & $\pm \mathrm{SD}$ & mean & $\pm \mathrm{SD}$ & t-value & $\mathrm{P}$ \\
\hline Body weight, kg & 1.02 & 0.13 & 3.14 & 0.27 & 3.14 & 0.25 & -0.067 & 0.947 \\
\hline Trunk length, $\mathrm{cm}$ & 23.9 & 1.8 & 36.3 & 1.4 & 37.5 & 1.8 & -1.894 & 0.070 \\
\hline Head length, $\mathrm{cm}$ & 11.6 & 0.7 & 15.3 & 0.5 & 14.9 & 0.6 & 1.880 & 0.072 \\
\hline Head height, $\mathrm{cm}$ & 4.8 & 0.3 & 6.3 & 0.3 & 6.1 & 0.3 & 1.761 & 0.091 \\
\hline Head width, $\mathrm{cm}$ & 3.6 & 0.2 & 4.7 & 0.1 & 4.7 & 0.1 & 1.265 & 0.218 \\
\hline Ear length, cm & 10.2 & 0.5 & 14.0 & 0.8 & 13.6 & 0.5 & 1.496 & 0.148 \\
\hline Ear width, cm & 6.0 & 0.3 & 7.8 & 0.4 & 7.3 & 0.2 & 3.177 & 0.004 \\
\hline Heart girth, cm & 18.6 & 0.8 & 29.3 & 0.8 & 30.7 & 1.0 & -4.022 & 0.000 \\
\hline Rump width, $\mathrm{cm}$ & 3.9 & 0.3 & 5.7 & 0.5 & 6.2 & 0.3 & -2.719 & 0.012 \\
\hline $\mathrm{FCL}, \mathrm{cm}$ & 5.6 & 0.2 & 8.4 & 0.3 & 8.4 & 0.3 & -0.196 & 0.846 \\
\hline $\mathrm{RCL}, \mathrm{cm}$ & 8.9 & 0.3 & 12.9 & 0.4 & 13.0 & 0.4 & -0.578 & 0.569 \\
\hline
\end{tabular}

FCL: fore cannon length; RCL: rear cannon length; Group AL: ad libitum; Group RS: restricted

Allometric growth of rabbit organs and body components was described by Deltoro and López (1985) as well as by Petersen et al. (1988). Our results on body composition (Table 5 and Fig. 1) are similar to those obtained by Bikker et al. (1996) for gilts. Perrier and Ouhayoun (1996) also found that rationing at an early age delayed skeletal development but at 8-11 weeks of age it mostly hindered fat deposition. In this study, restricted feeding caused a significant $(\mathrm{P}<$ 0.05 ) accretion of fat (10.0 vs. $14.7 \%$ of total body and 29.4 vs. $39.0 \%$ of dry matter, RS vs. AL rabbits, respectively). There were no significant differences in total body protein and ash. Calculating the parameters of chemical maturity (Moulton, 1923), i.e. ash/Fat Free Dry Matter (FFDM) $(17.87,13.77,14.31)$ and CP/FFDM, \% (78.42, 84.59, 84.14, before and after the trial, Group AL and Group RS, respectively), it can be stated that 6 week old rabbits did not reach chemical maturity (Fekete et al., 1997), but rabbits at the end of the trial did, like in the study of Coudert and Lebas (1985). 
Table 4

Means and standard deviations of traits studied in female New Zealand White rabbits (mean $\pm \mathrm{SD}$ )

\begin{tabular}{|c|c|c|c|c|c|c|c|c|}
\hline \multirow{3}{*}{ Indices } & \multirow{2}{*}{\multicolumn{2}{|c|}{$\begin{array}{l}\text { Before the trial } \\
(\mathrm{n}=26) \\
\text { Week } 6\end{array}$}} & \multirow{2}{*}{\multicolumn{2}{|c|}{$\begin{array}{l}\text { Group AL } \\
(\mathrm{n}=13)\end{array}$}} & \multirow{2}{*}{\multicolumn{2}{|c|}{$\begin{array}{c}\text { Group RS } \\
(\mathrm{n}=13)\end{array}$}} & \multirow{2}{*}{\multicolumn{2}{|c|}{$\begin{array}{c}t \text {-test } \\
\text { (between AL-RS) }\end{array}$}} \\
\hline & & & & & & & & \\
\hline & mean & $\pm \mathrm{SD}$ & mean & $\pm \mathrm{SD}$ & mean & $\pm \mathrm{SD}$ & t-value & $\mathrm{P}$ \\
\hline Index 1 & 159.28 & 14.6 & 361.0 & 24.0 & 336.7 & 27.9 & 2.378 & 0.026 \\
\hline Index 2 & 30.6 & 2.6 & 54.4 & 5.7 & 49.8 & 3.1 & 2.534 & 0.018 \\
\hline Index 3 & 63.8 & 2.8 & 65.1 & 2.6 & 64.9 & 1.2 & 0.284 & 0.779 \\
\hline Index 4 & 56.3 & 5.9 & 26.8 & 1.9 & 27.1 & 2.1 & -0.298 & 0.769 \\
\hline Index 5 & 462.5 & 58.0 & 1653.1 & 134.5 & 1913.7 & 168.7 & -4.365 & 0.000 \\
\hline Index 6 & 34.9 & 5.4 & 22.0 & 2.5 & 17.7 & 1.9 & 4.893 & 0.000 \\
\hline Index 7 & 54.6 & 7.5 & 107.0 & 7.6 & 102.4 & 7.8 & 1.519 & 0.141 \\
\hline Index 8 & 60.4 & 6.4 & 63.9 & 8.3 & 60.7 & 2.4 & 1.338 & 0.194 \\
\hline Index 9 & 61.5 & 5.1 & 58.5 & 1.9 & 56.8 & 3.1 & 1.718 & 0.099 \\
\hline
\end{tabular}

Index 1: head capacity $(\mathrm{HC})$; Index 2: ear surface; Index 3: fore cannon length $(\mathrm{FCL}) /$ rear cannon length $\times 100$; Index 4: FCL/body weight $(\mathrm{BW}) \times 10$; Index 5: body capacity $(\mathrm{BC})$; Index $6: \mathrm{HC} / \mathrm{BC}$ $\times 100$; Index 7: BW/heart girth $\times 1000$; Index 8: trunk length/rump width $\times 10$; Index 9: extremities/trunk length; Group AL: ad libitum; Group RS: restricted

Table 5

Body composition of female New Zealand White rabbits

\begin{tabular}{|c|c|c|c|c|c|c|c|c|c|}
\hline \multirow{2}{*}{ Animals } & \multirow{2}{*}{$\mathrm{n}$} & \multicolumn{4}{|c|}{ Total body composition, $\%$} & \multicolumn{3}{|c|}{ Dry matter components, $\%$} & \multirow{2}{*}{ FFDM } \\
\hline & & DM & Ash & $\mathrm{CP}$ & $\mathrm{EE}$ & Ash & $\mathrm{CP}$ & $\mathrm{EE}$ & \\
\hline \multirow{2}{*}{$\begin{array}{l}\text { Before trial, } 6 \mathrm{w} . \\
\pm \mathrm{SD}\end{array}$} & 10 & $25.6^{\mathrm{a}}$ & $3.9^{\mathrm{a}}$ & $17.3^{\mathrm{a}}$ & $3.5^{\mathrm{a}}$ & $15.4^{\mathrm{a}}$ & $67.6^{\mathrm{a}}$ & $13.8^{\mathrm{a}}$ & \multirow[t]{2}{*}{$86.2^{\mathrm{a}}$} \\
\hline & & 0.7 & 0.3 & 0.7 & 0.7 & 1.4 & 2.6 & 2.3 & \\
\hline \multirow{2}{*}{$\begin{array}{l}\text { End of trial, } \mathrm{AL} \\
\pm \mathrm{SD}\end{array}$} & 13 & $37.3^{\mathrm{b}}$ & $3.1^{\mathrm{b}}$ & $19.2^{\mathrm{b}}$ & $14.7^{\mathrm{b}}$ & $8.4^{\mathrm{b}}$ & $51.6^{\mathrm{b}}$ & $39.0^{\mathrm{b}}$ & \multirow[t]{2}{*}{$61.0^{\mathrm{b}}$} \\
\hline & & 2.3 & 0.3 & 0.8 & 2.9 & 1.0 & 4.5 & 5.7 & \\
\hline \multirow{2}{*}{$\begin{array}{l}\text { End of trial, RS } \\
\pm \mathrm{SD}\end{array}$} & 13 & $33.8^{\mathrm{c}}$ & $3.4^{\mathrm{b}}$ & $20.0^{\mathrm{c}}$ & $10.0^{\mathrm{c}}$ & $10.1^{\mathrm{c}}$ & $59.4^{\mathrm{c}}$ & $29.4^{\mathrm{c}}$ & \multirow[t]{2}{*}{$70.6^{\mathrm{c}}$} \\
\hline & & 1.7 & 0.4 & 0.5 & 1.8 & 1.3 & 3.2 & 3.9 & \\
\hline
\end{tabular}

AL: ad libitum; RS: restricted; DM: dry matter; CP: crude protein; EE: ether extract; FFDM: fatfree dry matter; Values in a column with different superscript letters (a, b, c) differ at $\mathrm{P}<0.05$

Restricted feeding may have caused a sensation of hunger which, in turn, increased the water intake. The extra water was retained only partly $(3.5 \%$ difference in dry matter content), and mostly diluted the urine, because the dry matter content of the faeces excreted by rabbits of the two groups did not differ significantly (66.68 vs. $73.52 \%$ ). Restricted feeding decreased final liveweight and body fat content and increased relative ash and protein concentration. AL rabbits reached the sexual maturity significantly earlier. As the data of Table 6 suggest, 
owing to the lack or decreased number of LH receptors answer to hCG was weaker and the FSH and LH production of RS rabbits was lower.

Data suggest the significance of body fat in the onset of puberty (Frisch, 1994). In spite of the findings of Hartmann and Petersen (1995, 1997), who found an improvement of reproductive performance of restricted-fed does in the second and third lactation, our findings are closer to the statement of Rommers et al. (1999), i.e. that reproductive organs have a higher growth rate between weeks 10 and 18, and thus, considering the short life span of does, there is no reason to practice feed restriction in the case of growing female breeding rabbits.

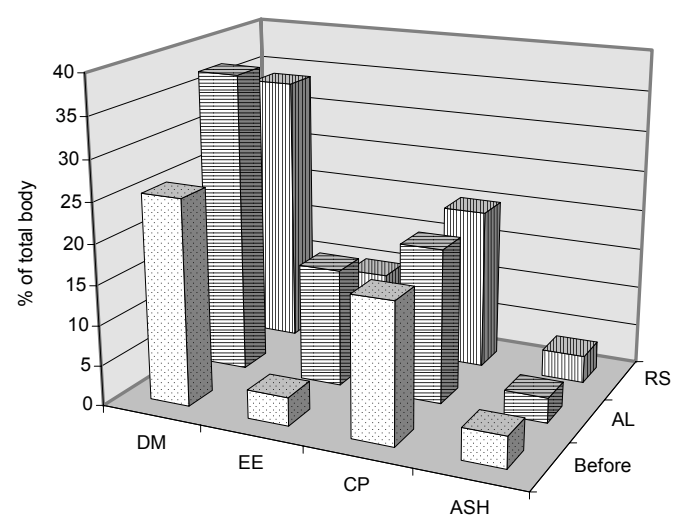

Fig. 1. Total body composition of female growing rabbits of different rearing intensity. RS: restricted (at week 18); AL: ad libitum (at week 18); Before: at the beginning of the trial (at week 6); DM: dry matter; EE: ether extract; $\mathrm{CP}$ : crude protein $(\mathrm{N} \times 6.25)$

Between the age of 8 and 11 weeks, no correlation between feeding intensity, hormone treatment and reproductive stage was found. No difference in oestrous symptoms was observed, as slight vulvar swelling and hyperaemia were seen in both groups. The teaser male mounted all the does but none of them was receptive to mating. At the age of 12-13 weeks, the effect of feeding was obvious. In Group AL 75\% of the does seemed to be in oestrus regardless of the type of hormonal treatment. In Group RS $40 \%$ of the animals showed similar symptoms. Since they still refused mating, the symptoms were not considered as normal oestrus. The clinical picture may be related to a low level of $17 \beta$-oestradiol production in the developing follicles. At that age, regardless of the feeding regime, the plasma $\mathrm{P} 4$ levels remained below the limit value, $1 \mathrm{nmol} / 1(0.71 \pm$ $0.92 \mathrm{nmol} / \mathrm{l})$. It can be concluded that until the age of 13 weeks both ovarian and adenohypophyseal responsiveness are lacking. Neither of the two hormone treatments was able to provoke follicular maturity and rupture. At the age of 1415 weeks, the situation was the same. At 16 weeks of age, $92 \%$ of the does fed ad libitum showed active sexual functions. In $25 \%$ of the cases, spontaneous 
oestrus with pronounced clinical symptoms and receptivity was seen. Follicular rupture and cyclic corpus luteum (CL) formation was also observed. The plasma progesterone levels of the pregnant does were elevated $(13.11 \pm 0.89 \mathrm{nmol} / \mathrm{l})$, the horns of the uteri contained embryos (right side: $5.0 \pm 0.82$; left side: $3.33 \pm$ 0.47 ). In a pseudopregnancy, typical clinical symptoms of oestrus could be observed without receptivity. The active hormone producing CL (right side: 5 , left side: 2 CL graviditatis) were associated with $12.89 \mathrm{nmol} / 1 \mathrm{P} 4$ level and the secretion stage of the uterus. The adenohypophysis seemed to produce sufficient amounts of FSH and LH. Sixty-nine percent of the does kept on restricted feeding showed active sexual activity with slight oestrous symptoms. One animal became pregnant $(25.31 \mathrm{nmol} / 1$ progesterone level) with embryos in the uteri (right side: 7 ; left side: 3 ).

\section{Table 6}

Total and mean number of tertiary follicles (F3), corpora lutea (CL), luteal structures (Ls), embryos (E) and state of uterus (U) at 18 weeks of age

\begin{tabular}{llll}
\hline & \multicolumn{1}{c}{ Group AL } & Group RS & \multicolumn{1}{c}{$\mathrm{P}$} \\
\hline F3 & $\mathrm{n}=13 ; 322$ & $\mathrm{n}=13 ; 337$ & $>0.05$ \\
& 24.77 & 25.92 & \\
CL & $\mathrm{n}=10 ; 89$ & $\mathrm{n}=8 ; 59$ & \\
& 8.9 & 7.38 & $>0.05$ \\
Ls & $\mathrm{n}=9$ & $\mathrm{n}=8$ & \\
E & $\mathrm{n}=3$ & $\mathrm{n}=1$ & \\
& 25 & 10 & \\
U & G/S: $7 ;$ & G/S: $4:$ & \\
& PsG/S: $3 ;$ & PsG/S: 2 & \\
& I/P: 3 & I/P: 7 & \\
\hline
\end{tabular}

Group AL: ad libitum; Group RS: restricted; G/S: gravid/secretion; PsG/S: pseudogravid/secretion; I/P: inactive/proliferation

At $17-18$ weeks of age $70 \%$ of the does in Group AL showed active ovarian and uterine function, irrespective of whether the trigger of oestrus was mating or hormonal treatment. Progesterone levels were elevated to $9.01 \pm$ $1.98 \mathrm{nmol} / 1$ and $10.31 \pm 1.82 \mathrm{nmol} / \mathrm{l}$ in pregnant and pseudopregnant does, respectively, and active CL were seen on the ovarian surface and early stage embryos were found in the uteri (Table 5). One doe with moderate oestrous signs showed receptivity and was mated but follicular rupture failed to occur according to progesterone levels $(0.17 \mathrm{nmol} / \mathrm{l})$ and ovarian histology (primary and secondary follicles). Reflex ovulation probably failed due to LH insufficiency (oestrus and receptivity with anovulatory cycle). In $30 \%$ of the does of Group AL, no 
ovarian response was seen (anoestrus). At 17-18 weeks of age, $58 \%$ of the does of Group RS showed ovarian activity spontaneously or in response to hormone treatment. One-third of does previously failing to conceive were mated with moderate or weak clinical symptoms and with the exception of a single doe all of them conceived. Progesterone levels rose to $6.83 \pm 3.15 \mathrm{nmol} / \mathrm{l}$, active CL were present on the ovarian surfaces, and early embryos were found in the uteri. In two does GnRH-provoked oestrus induction was followed by clinical oestrus without receptivity. Their progesterone levels (13.92 and $11.47 \mathrm{nmol} / \mathrm{l})$, the active CL and the secretory stage of the uterine epithelium suggest pseudopregnancy (hormonally induced ovulation). Forty-two percent of the rabbits of Group RS showed ovarian inactivity and silent uterine picture. One animal with anoestrus showed receptivity, accepted the buck, but no histological evidence was found for follicular rupture or CL formation. On the ovaries of both sides, luteal structures (irregular CL) were seen (receptivity without oestrus).

In agreement with the findings of Maertens (1984), restriction of feeding to $70 \%$ of the ad libitum level resulted in reduced fat content of body, and therefore diminished sexual activity, with the following symptoms:

(a) ovarian activity started later and ovarian responsiveness was weaker with a smaller number of tertiary follicles on the ovarian surface,

(b) response to hCG treatment was weaker due to a smaller number of ovarian LH receptors, and

(c) the pituitary response and FSH/LH production capacity was lower.

Rabbits are able to adjust their feed (dry matter) intake rapidly to the digestible energy content (Lebas et al., 1982). Nevertheless, data indicating positive effects of feed restriction in replacement does can be found in the literature (Proud'hon et al., 1975). Maertens and Villamide (1998) accepted both ad libitum and restricted feeding for young does, according to the desired mating time. In the light of the results obtained in this study, the quantitative restriction of feed intake cannot be accepted during the raising of future breeding does, because this would not only delay the onset of sexual maturity but also change the growth of different body parts.

\section{Acknowledgements}

This research was supported by grants from the Hungarian Scientific Research Fund (OTKA T/030359 and T/0266069) and from the Ministry of Culture and Education (FKFP 0644/97). 


\section{References}

Adam, C. L. and Robinson, J. J. (1994): The role of nutrition and photoperiod in timing of puberty. Proc. Nutr. Soc. 53, 89-102.

Ayyat, M. S., Marai, I. F. M. and El-Sayiad, G. A. (1995): A trail to grade New Zealand White rabbits for broiler production at marketing and breeding. World Rabbit Sci. 3, 75-84.

Bikker, P., Verstegen, M. W. and Campbell, R. G. (1996): Performance and body composition of finishing gilts (45 to $85 \mathrm{~kg}$ ) as affected by energy intake and nutrition in earlier life. II. Protein and lipid accretion in body components. J. Anim. Sci. 74, 817-826.

Cizek, L. (1961): Relationship between food and water ingestion in rabbit. Am. J. Physiol. 201, 557-566.

Codex Pabularis Hungaricus (1990): MÉM-MMI, Budapest (in Hungarian).

Coudert, P. and Lebas, F. (1985): Production et morbidité des lapins reproductrices. 1. Effets du rationnement alimentaire avant et pendant la premiere gestation. Ann. Zootech. 34, 31-48.

Deltoro, J., López, A. M. (1985): Allometric changes during growth in rabbits. J. Agric. Sci. 105, 339-346.

Eiben, Cs., Kustos, K., Kenessey, Á., Terenyi, E., Virág, Gy. and Szendrő, Zs. (1998): Effect of different degrees of feed restriction during raising upon the milk production of rabbit does (in Hungarian, with English abstract). In: Szendrő, Zs. (ed.) Proceedings of the 10th Rabbit Breeding Scientific Day (10. Nyúltenyésztési Tudományos Nap előadásai), PATE, Kaposvár, pp. 63-70.

Fekete, S. (ed.) (1995): Veterinary General Nutrition (in Hungarian). Lecture note of the University of Veterinary Science, Budapest, pp. 208-222.

Fekete, S. and Bokori, J. (1985): The effect of the fiber and protein level of the ration upon the cecotrophy of rabbit. J. Appl. Rabbit Res. 8, 68-71.

Fekete, S. and Brown, D. L. (1993): The major chemical components of the rabbit whole body measured by direct chemical analysis, deuterium oxide dilution and total body electrical conductivity. J. Vet. Nutr. 2, 23-29.

Fekete, S. and Gippert, T. (1981): Studies on the effect of different restricted rations in broiler rabbit production (in Hungarian, with English abstract). Magyar Állatorvosok Lapja 36, 484-488.

Fekete, S., Hullár, I., Andrásofszky, E., Bersényi, A. and Szakáll, I. (1997): Changes in body composition of growing rabbits owing to age and sex. Z Ernährungswiss. 36, 326.

Frisch, R. E. (1994): The right weight: body fat, menarche and fertility. Proc. Nutr. Soc. 53, 113-129.

Gáspárdy, A., Eszes, F., Bodó, I., Koppány, G., Keszthelyi, T. and Márton, F. (2001): Type comparison of different Hungarian Tsigaja (Berke) sheep variants (in Hungarian, with English abstract). Állattenyésztés és Takarmányozás 50, 33-42.

Hartmann, J. and Petersen, J. (1995): Vergleichende Untersuchungen zur Reproduktionsleitung von während der Aufzuchtphase und ad libitum gefütterten Zuchthäsinene. 9th Symposium on Housing and Diseases of Rabbits, Fur-bearing Animals and Pet Animals, Celle, pp. 97-105.

Hartmann, J. and Petersen, J. (1997): Körpergewichtsentwicklung und Milchleistung in den ersten drei Wochen der Laktation in Abhängigkeit von der Aufzuchtintensität von Hybridhäsinnen. 10th Symposium on Housing and Diseases of Rabbits, Fur-bearing Animals and Pet Animals, Celle, pp. 24-32.

Huszenicza, Gy., Fekete, S., Haraszti, J., Molnár, L. and Solti, L. (1988): Ovarian activity after the first calving in cows reared under different farm conditions. Acta Vet. Hung. 36, 153-164.

Huxley, J. S. (1932): Problems of relative growth. Methuen \& Co., London.

Jakubec, V., Rafay, E., Rehác, E. and Parkányi, V. (1985): Analysis of gene action in the control of body weight from birth to 84 days of age in the rabbit. Z. Tierzucht. Züchtungskunde 108, 285-291.

Lebas, F., Laplace, J. P. and Droumenq, P. (1982): Effect of the dietary energy content in rabbits. Variations according to age of animals and feeding sequences. Ann. Zootech 31, 233-256. 
Maertens, L. (1984): Overzicht van ankele proeven met konijnen op het R. V. K. 1. Opfok van jonge voedsters. NOK Kontaktblad 2, 79-85.

Maertens, L. (1995): Energy and nutrient requirements of does and their young. Proc. 9th Symposium on Housing and Diseases os Rabbits, Fur-bearing animals and Pet Animals, Celle, pp. 76-91.

Maertens, L. (1997): Effect of closing of the nestbox and flushing on doe fertility. 2nd IRRG Meeting 'Rabbit reproduction: research and practical application', Gödöllö.

Maertens, L. and Villamide, M. J. (1998): Feeding systems for intensive production. In: De Blas, C. and Wiseman, J. (eds) The Nutrition of the Rabbit. CABI Publishing, Wallingford, Oxon, pp. 255-272.

Moulton, C. R. (1923): Age and chemical development in mammals. J. Biol. Chem. 57, 79-97.

Nagy, P., Solti, L., Kulcsár, M., Reiczigel, J., Huszenicza, Gy., Abaváry, K. and Wölfling, A. (1998): Progesterone determination in equine plasma using different immunoassays. Acta Vet. Hung. 46, 501-513.

Nouris, M. J. (1988): SPSS/PC+ V.3.0. Update Manual. SPSS Inc., Chicago.

Parigi Bini, R., Xiccato, G., Dalle Zotte, A., Garazzolo, A., Castellini, C. and Stradaioli, G. (1996): Effect of remating interval and diet on the performance and energy balance of rabbit does. Proc. 6th World Rabbit Congress, Toulouse, vol. 1, pp. 253-258.

Perrier, G. and Ouhayoun, J. (1996): Growth and carcass traits of the rabbit. A comparative study of three modes of feeding rationing during fattening. In: Proc. 6th World Rabbit Congress. Toulouse, vol. 3, pp. 225-232.

Petersen, J., Schweicher, I. and Gerken, M. (1988): The age-related development of body composition of hybrid rabbits. Züchtungskunde 60, 72-84.

Prud'hon, M., Cherubin, M., Carles, Y. and Goussopoulos, J. (1975): Effects of different levels of water restriction on the food intake of rabbits. Ann. Zootech. 24, 299-310.

Püski, J., Bozó, S., Borka, Gy., Györkös, I., Gáspárdy, A. and Szücs, E. (2001): Vergleich von vier Merkmalen innerhalb der 50-punkte-Exterieurbeurteilung mit den erfaßten Körpermassen bei Holstein-Friesian Kühen. Arch. Tierzucht. 44, 33-45.

Rommers, J. M., Kemp, B., Meijerhof, R. and Noordhuizen, J. P. T. M. (1999): Rearing management of rabbit does: a review. World Rabbit Sci. 7, 125-138.

Szendrō, Zs., Szabó, S. and Hullár, I. (1988): Effect of reduction of eating time on production of growing rabbits. Proc. 4th World Rabbit Congress, Budapest, vol. 3, pp. 104-114.

Tag-El-Den, T. H., Mervat, A. A. and Molnár, J. (1988): Effect of restricting feeding periods on feed intake and digestibility of dry matter in rabbits. Proc. 4th World Rabbit Congress, Budapest, vol. 3, pp. 213-222.

Zöldág, L. (1990): The reproduction of the domestic rabbit. In: Vetési, F. (ed.) Health and Diseases of the Domestic Rabbit (in Hungarian). Mezőgazdasági Kiadó, Budapest, pp. 62-77. 